\title{
Art Criticism in Comics Grey \& Jingga: The Twilight by Sweta Kartika
}

\author{
Wrin Probo Tyas ${ }^{1}$ Trie Hartiti Retnowati ${ }^{2}$ I Wayan Suardana ${ }^{3}$
}

\author{
${ }^{1}$ Universitas Negeri Yogyakarta, Yogyakarta, Indonesia \\ ${ }^{2}$ Universitas Negeri Yogyakarta, Yogyakarta, Indonesia \\ ${ }^{3}$ Universitas Negeri Yogyakarta, Yogyakarta, Indonesia \\ ${ }^{*}$ Corresponding author.Email: wrinprobotyas@gmail.com
}

\begin{abstract}
The background of this research is to understand and know created art and delivered the message, so that all of these things can determine the quality of an art work. The elements of art criticism in the Grey \& Jingga comics are (1) description, (2) formal analysis, (3) interpretation, and (4) assessment or evaluation. This research used a descriptive qualitative method. The main data source of this research was the Grey \& Jingga comics. The results of this research were about the understanding and delivery of messages to an artwork produced by an artist through art criticism, so that all of these things can determine the quality of an art work. Keywords: Art Criticism, Comics, Grey \& Jingga, Sweta Kartika.
\end{abstract}

\section{INTRODUCTION}

Artwork is an inspiration from an artist in various forms of work, including comics. For example, comics by Indonesian artists are still rarely known by the general public, especially a fact that there are still many people who prefer comics from other countries. Therefore, this study raises the theme of Comics Grey \& Jingga created by Sweta Kartika, an Indonesian comic artist.

The art of criticizing means evaluating or researching artworks or literature. Criticism can be interpreted as a process of scientific investigation of texts or documents related to the work authenticity. Before criticizing art, we need to know the meaning of art criticism first. What is art criticism? In the English-Indonesian dictionary, the meaning of the word "critic" is discussion [1] [4]. Meanwhile, Bahari himself concluded that art criticism is the expression of opinions for certain reasons on various things including values, truth, policy, beauty, or techniques in creating art. The aim of art criticism is that people who see the artwork obtain information and understanding relating to the quality of an art work, and foster appreciation and response to art [5].

Art criticism talks about how to understand a work of art easier with all aspects. Djelantik [3] states that art criticism is intended to describe art or the art assessment. People often assume that criticism means negative things. In fact, art criticism does not mean to be aggressive, threatening, either intentionally or not, but it is only to provide an assessment of a work, whether it is good or not, of course, viewed from several aspects, not subjectively. Art criticism serves as a mediator between the creator and connoisseurs of art works, and between the work of art itself and the audience. The function of art criticism is very important, because not all connoisseurs of art works can know for certain what is conveyed and communicated by the creators with the form of the work presented. In carrying out art criticism verbally and in writing, usually there are elements of art criticism.

The first element of criticism in the Grey \& Jingga comics by Sweta Kartika is a description. In the art description, there will be an illustration of what is presented in the comics. A description of the visible visuals will also be presented in this part. In this section, criticism has not been conveyed, so that explanations regarding art can be revealed properly. A systematic use of the art criticism elements can be done sequentially or randomly depending on the intended purpose of it.

The second element in Sweta Kartika's Grey \& Jingga comics art criticism is a formal analysis. In the formal analysis, the results of the work will be explained with some data that appear visually. First, the artwork will be analyzed regarding the quality of visual elements and will be detailed in the art elements, namely the quality of lines, areas, colors, and textures.

The third part of the Grey \& Jingga comics art criticism is interpretation. Like the term, in this section, the artwork will be interpreted based on the meaning, message, and value contained therein. The final stage in art criticism is assessment or evaluation. In the evaluation, it discusses all explanations from the first stage to the third stage, namely description and interpretation of art that will produce an assessment.

Based on the description, the work presented by artists can represent the expressions of each artist whose content is an expression substance that refers to various themes, interpretations, or experiences of their life. Each artwork has its own uniqueness/characteristics, as found in the Grey \& Jingga comics by Sweta Kartika. The findings of research in art criticism especially in the comics are about 
understanding and delivering messages to an artwork created by an artist through art criticism, so that all of these things can determine the quality of an artwork.

\section{METHOD}

The research design used in this study was a descriptive qualitative method; it is to observe objectively and directly based on the visualization/form of the narrative work itself. The main data source of this research is Comics Grey \& Jingga by Sweta Kartika. This data collection was carried out by studying the comics. The design of this study was used in accordance with the objectives of this research, namely to understand and to find out the background of the artwork produced through the description, formal analysis, interpretation, and assessment/evaluation of the work in the Comics Grey \& Jingga by Sweta Kartika.

\section{DISCUSSION}

In the art criticism, assessment can be carried out generally or non-generally. What is meant by the general form is the assumption that valuing works of art must be based on an analysis of the art elements separately. Whereas, in the non-general form, the value of an artwork is not fragmented. In a non-general assessment, artwork is considered as a whole.

This article will discuss the elements of art criticism in the Grey \& Jingga comics by Sweta Kartika. However, before entering the art criticism section, it would be better to review the definition of comics. Alex in Sugiharto et al. [8] states that:

Comics in general are illustrated stories found in magazines, newspapers, or books, which are generally easy to understand and funny.

The word comics comes from the English word "comics" which means everything that is funny and entertaining [4]. Meanwhile, in a general Indonesian dictionary, the word 'comics' is generally interpreted as a picture story (in magazines, newspapers, or books).

"Sequential Art" is called as comics by an expert Will Eisner. The pictures if standing alone and viewed one by one are still only an image. When the pictures are arranged sequentially, even though it only consists of two images, the art in the picture changes in value to the comic art [7].

Comics must be displayed in different frames by spacing each frame or panel. The distance in the comics works the same as the time in the film [7]. Furthermore, McCloud [7] defines comics as follows:

Comics are pictures and other symbols that are arranged side by side in a certain order, aimed at providing information and or achieving aesthetic responses from readers.

The aim of comics is to entertain readers with light reading and not to always carry themes that convey certain moral values. Based on the type, comics are divided into two types namely comic strips and comic books. A comic strip is a series published in newspapers or magazines. Then, a comic book is a collection of illustrated stories consisting of one or more theme titles.

\subsection{Artwork Description}

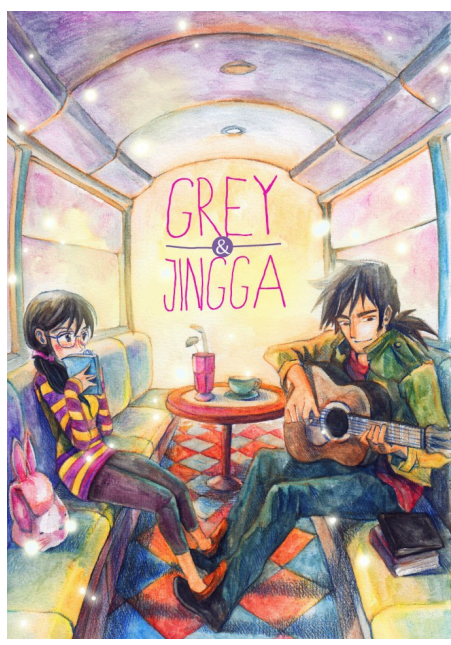

Figure 1 Cover of Grey \& Jingga Comics: The Twilight

Grey \& Jingga Comics are made by Sweta Kartika, published by M\&C since 2014. This comic tells a romance of college teenagers namely Grey, Jingga, and some of their friends. The artist illustrates their story as twilight. Jingga is like an orange canvas stretching in the twilight sky, while Grey is a collection of gray clouds that take him home. One of the characters, Jingga, falls in love with Grey, a man who apparently has fallen in love with Jingga since he was a child. Both are unique characters but it sounds like a cliché. She has a cool personality who doesn't care, while Grey is indifferent but romantic; it ultimately creates emotion tug between the two.

People assume that the stories in these comics can raise the theme of romance without making it look excessive. The comic artist, Sweta Kartika, wants to portray the character of Indonesian women in general with the figure of Jingga. Meanwhile, Grey is a figure that portrays men in Indonesia who are less sensitive to women's feelings. When viewed from the theme of the book, it lifts an issue of childhood to adulthood in the love life.

If we look at it from the plot side, these comics are presented in the form of a comic strip, with each page differing from one another but interconnected. Each comic page is presented in five panels which form a unified story line. The plot sequence starts with an introduction and then conflict, which leads to climax, and ends in resolution. They seem to be a sequence in simple short texts. More interestingly, there is a quote on each page of the comics. This is very much related to love issues of young people in general. This makes the readers interested in it. 


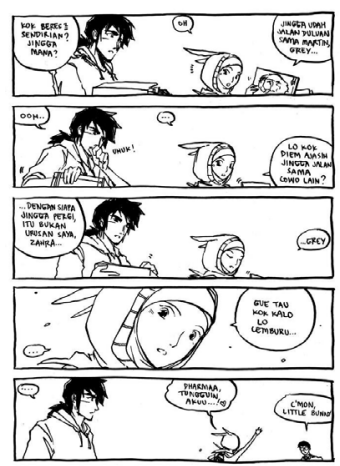

Figure 2 There Are Five Panels in One Comic Page

From the types of the comic depictions itself, this comic uses drawings made manually without using tools, even the grid on each page is in black and white. This can be seen from the irregular lines on the panel. This brings a light impression to the readers; the style also looks simple. Even the language used is simple because it uses casual language (informal), so that readers will not see it as something rigid. The shading used by the comic artist does not offer excessive impression. How to make the angle is varied. Moreover, the proportion of each object in harmony makes it easy for the readers to enjoy it. The issues raised in this comic are related to daily problems.

At first, these comics were only published for free on Sweta Kartika's Facebook. Apparently, there are many people who like his work, so that some publishers tried to publish his comics. However, in the beginning, Sweta Kartika thought that it would be impossible to bring profit, because the comics had been published on Facebook. After some persuasion by his friend, these comics were published in the form of a comic book. There were several sections in the comics added to the published books. The example is the Grey and Jingga encounter which is told in detailed in the comic book than in the comic strips.

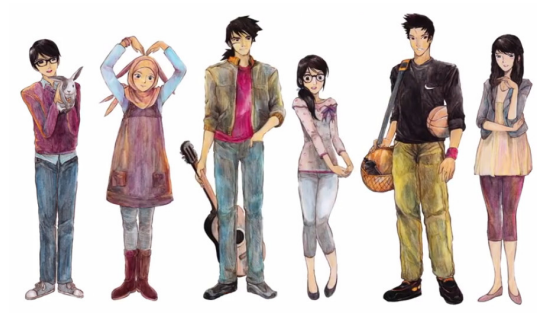

Figure 3 Characters in Comics Grey \& Jingga

This comic is presented in two forms, in color and in black and white. The black and white version is published in the form of a comic book, while the colored one is published in a webtoon. In the colored version, these comics are drawn using digital tools. The depictions of the figures use light pastel colors.

\subsection{Formal Analysis}

As mentioned in the work description, the comics use manual drawing techniques without tools. At the first glance, it will be very clear that this is a manual drawing. The lines on the panel are not too straight as one proof that these comics are manually drawn. Maybe, if we compare it with comics from other countries, these comics are different in terms of character coloring. The drawing technique is like using watercolors on paper if we look at glance. There is an old-fashioned impression on the picture because of the gradations of color that are not common. However, overall, it still looks interesting.

The elements of visual art forms consist of points, lines, and spaces [3]. In addition, Bahari [2] also revealed that the existence of art is very much determined by the appearance of visual art elements that surround them. These elements are in the form of lines, shapes, color spaces, and so on. All elements of fine art must be present to create a certain image.

When viewed from the dots, Sweta uses a lot of dots in adding accents to the images. The lines contain more meaning than points, because from their own shape, the lines will give a certain impression to the reader's eyes. Strong lines give a different feeling than the curved ones. For example, it can be seen in the formation of the characters of lips. If the lip line is drawn up, it indicates that the character is smiling. If the line is drawn straight, it means that the character is thinking or is not happy with a situation. It can also be expressed with a cool character. Lip lines drawn down, for example, depict characters who are sad, angry, or unhappy with something. Nevertheless, the interpretation of the lip small lines will return to the context in the comic story line.

Style deals with the external or physical form of an artwork. Decoration is a style, because this term is used to name a painting highly decorated with distinctive patterns [9].

The shape of each space can give a different aesthetic impression. In these comics, the portrayal of the field is formed in a rigid angle. It does not mean something bad, but it is the comic artist's drawing style. It is similar to the depiction of the Grey hair which is stiff at the ends, or the shape of the face on each character that tends to be sharp rather than blunt. This brings an ancient impression on the comics itself. The current trend is more describing the oval character shape on the face and other angles such as the elbow or ler chane

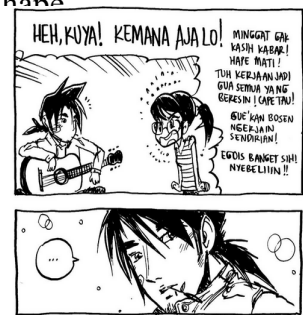

Figure 4 A Speech Balloon Showing an Expression. 


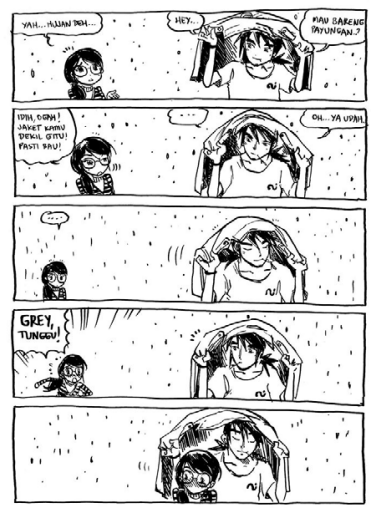

Figure 5 The use of Visual Art Elements

As mentioned in the art description, this comics use manual drawing techniques. At the first glance, it will be very clear that this is a manual drawing. It is also proven by the lines on the panel which are not too straight. Maybe if we compare with other countries' comics, this is different in terms of character coloring. The drawing technique is like using watercolors on paper. There is an old impression on the picture because of the color gradations that are not found in common comics, but overall it still looks interesting.

The distance among the panels is neither too tight nor too tenuous. In addition, there is a description of the word balloon referring to the character's expression or emotion when talking such as angry, shouting, afraid, whispering, and talking to himself. The comics use the line effect, where the lines are created and used to indicate motion or speed.

The character development in these comics is quite unique, although it is considered general. The personalities of the characters can be seen at a glance by looking at the face shape depicted in the comics. For example, the Grey character that is portrayed as a cool guy has a flat expression and deep eyes. It is not only Grey character that describes the personalities of each character. The Jingga character with a rather shy figure is depicted on the appropriate face and expressions. She also wears glasses to create smart impression that the comic artist wishes to convey. The comic artist is able to present his characters well.

\subsection{Interpretation}

Conveying the meaning of works of art is an important element that cannot be discarded. A work is the inspiration of an artist, where the work can convey feelings the artist wants to express. However, there are some artists able and unable to express and convey meanings well. That is why there are interpretations of art to help interpret the meaning of art.

Each interpretation can reveal things related to the statement behind the structure of the form, such as the background, ideas, abstraction, position, desire, belief, and experience of the artist. In order to explain correctly, an interpreter must have knowledge of the process of changing the work [5].

In conveying the meaning, realization is very important, as expressed by Gaut [6]:

\begin{abstract}
One might wonder whether it matters whether emotional realism is true or not for our present purpose. For could not the cognitive and merited response arguments be defended without resource to emotional realism? Emotional irrealists could note that, when one learns thorough functional art, one may learn by imagining having certain emotions (imagining pity or scorn for Humbert, say), and that imagined emotions are powerfully educated of how we thought to feel are actual emotions.
\end{abstract}

To emphasize the realization of art in these comics, it is necessary to know an explanation of what emotion is. Emotion is something that is felt. It is also a condition which psychologically has a phenomenology. This means that when someone is in an emotional condition, he/she will experience mood swings or be more sensitive to something. An emotion gives a feeling to someone to feel sorry for others and afraid of someone. In other words, emotions have an object that triggers the emergence of these feelings. Gaut [6] said that emotion can motivate an action: I run away out of fear, I help someone because I feel sorry for him. A feeling will explain the current emotional state, but what is felt might come from one to another phenomenon, or from one to another person.

The comic artist, Sweta Kartika intends to bring romantic stories to young people, as the common issues. These comics were originally published unintentionally. The comic artist Sweta Kartika regularly publishes on his Facebook every Monday and Thursday. It is done because Sweta wants to change people's views about Monday, "I hate Monday". Sweta wants readers to look forward to reading these comics on Monday.

Sweta Kartika in figuring out the characters in the story succeeds to bring the hearts of readers, by his skills not only in drawing but also in writing. Although it is unfortunate that there is no climax in the comic, and the ending of the story is uncertain; overall these comics can amuse the readers.

In addition, the emotions that the comic artist wishes to express can be conveyed well to the readers, with evidence that I found in people's reviews. Most of them state that the comic succeeds in conveying the values and emotional meanings.

\subsection{Evaluation}

Art criticism in the world of fine art is very important. Through art criticism, we can see the strengths and weaknesses that appear in a work of art. The stages cover from simple to complicated things. The simple side is to describe what appears in a work of art, while the complicated one is at the stage of interpretation.

These comics began to be published online on Sweta Kartika's Facebook account in 2012. Initially, these comics only presented a comic strip with a different story on each 
page but still provided continuity to the story. Each comic page is presented in five panels which form a unified story line. The plot sequence starts with introduction, and then conflict which leads to climax, and ends in resolution. It sounds like a sequence in simple short texts. Even more interesting, there is a quote on each page of the comics. This quote is very much related to love issues that raise teenage themes, and this attracts the readers.

This comic is presented in colored and black-and-white versions. The black-and-white version is published in the form of a comic book, while the colored one is provided in a webtoon. In the colored version, this comic is drawn using digital tools for finishing the comics. The depictions of the characters use light pastel colors.

These comics have been artistically described by Sweta Kartika. The picture drawn is indeed interesting and distinctive, with fine scratches. When viewed from the side of the plot, these comics are presented in the form of a comic strip, with each page different from each other but interconnected. Each comic page is presented in five panels which form a unified story line.

Overall, almost all works of these comics are done manually, although they still need tools for finishing. When viewed from an artistic point of view, this is like old comics because the new model is neater in depicting characters made using a computer. The angle of the character shape is also different from the comics in general, which is currently popular. There is no doubt that Sweta Kartika is able to carry its special features in these comics. The color combination for me is not too beautiful, but it is still attractive, and it does not reduce my admiration for this work. Sweta Kartika in figuring out the characters in the story succeeds to bring the hearts of the readers, not only her skills in drawing but also with his smartness in rendering words. Although it is unfortunate that there is no climax in these comics, and the ending of the story is unclear. Overall, these comics can entertain its readers.

In addition, the emotions that the comic artist wishes to express can be conveyed well to the readers, with evidence that the authors read from the people's reviews. Most people say that the comic succeeds in conveying the meaning and emotions. It is because of its interesting story and the unique portrayal of the character. Overall, the authors will conclude that this is a successful work.

\section{CONCLUSION}

Artwork is an inspiration from an artist in various forms of work, including comics. The Grey \& Jingga Comic has been created by Sweta Kartika and published by M\&C since 2014. The comic tells the romance of teenagers namely Grey and Jingga, as well as some of their friends. The artist portrays their story like twilight.

There are several elements in the art criticism of the Grey \& Jingga Comics: The Twilight by Sweta Kartika. In the art description, there will be a depiction of what is presented in the artwork. The second part of art criticism is formal analysis, the third part is interpretation; and the final stage is assessment or evaluation. Based on the various elements of art criticism, overall the Comics Grey \& Jingga: The Twilight by Sweta Kartika can be considered as a successful work.

With art criticism, it is expected to understand the background of an artwork and message conveyed, so that all of these things can determine the quality of an art work.

\section{REFERENCES}

[1] Bahari, N. Kritik Seni [Art criticism]. Pustaka Pelajar, 2014.

[2] Bahari, Nooryan. Kritik Seni: Wacana, Apresiasi, Dan Kreasi [Art Criticism: Discourse, Appreciation, and Creation]. Pustaka Pelajar, 2008.

[3] AAM, Djelantik. "Estetika Sebuah Pengantar [An Easthetic Introductary]." Masyarakat Seni Pertunjukan Indonesia, Bandung (2004).

[4] Echols, John M., and Hasan Sadily. "Kamus Inggris-Indonesia [English-Indonesian dictionary]." Jakarta: Gramedia Pustaka Utama, Cet." Ke XXIV (2000).

[5] Feldman, Edmund Burke. "Art, Image and Idea, New Jersey: Prentic-Hall, inc." Englewood Cliffsd 10 (1967).

[6] Gaut, Berys. "Art and knowledge." The Oxford Handbook of Aesthetics (2003): 439-441.

[7] McCloud, Scott. "Understanding comics: The invisible art." Northampton, Mass (1993).

[8] Sugihartono, Ranang Angung, Basnendar Herryprilosadoso, and Asmoro Nurhadi Panindias. "Animasi Kartun: Dari Analog Sampai Digital [Cartoon Animation: From Analog to Digital]." Jakarta: Indeks (2010).

[9] Susanto, Mikke. Diksi Rupa: Kumpulan Istilah dan Gerakan Seni Rupa [Diksi Rupa: The Collection of Terms and Movements in Fine Arts]. DictiArt Lab, 2011. 